\title{
FGFR Gene Mutation
}

National Cancer Institute

\section{Source}

National Cancer Institute. FGFR Gene Mutation. NCI Thesaurus. Code C146713.

A change in the nucleotide sequence of an FGFR family gene. 